\title{
The effects of two Australian native grasses on the stability of soil cover on sulphidic gold mine tailings in the goldfields of southeastern Australia
}

\author{
A.I. Doronila School of Botany, The University of Melbourne, Australia \\ L. Yan Department of Civil and Environmental Engineering, The University of Melbourne, Australia \\ G.A. Narsilio Department of Civil and Environmental Engineering, The University of Melbourne, Australia \\ S.T.S. Yuen Department of Civil and Environmental Engineering, The University of Melbourne, Australia
}

\begin{abstract}
Wastes produced from gold mining often result in a large footprint for mining companies at the time of mine closure. These wastes which are impounded in large tailings storage facilities are generally highly contaminated with elevated levels of toxic minerals and compounds, e.g. arsenic and cyanide. Few plants could naturally colonise these wastes, presenting a difficult situation for the rehabilitation and revegetation of closed mine sites. With appropriate placement of relatively benign capping materials, a suitable plant cover can be established which can stabilise the wastes and reduce surface erosion. Grasses in particular have been identified as an important component of any phytostabilisation regime. Australian native grasses have been considered potential candidates for the revegetation of mine tailings in drier climate because of their suitability to the often harsh environment. They have been documented to have desirable attributes including deep roots to aid in stabilisation and tolerance to low nutrient, drought and saline conditions The objective of this study was to investigate the benefit of using two Australian native grasses, Themeda triandra and Bothriochloa macra, in improving the stability of a cap which consisted of a $5 \mathrm{~cm}$ sandy loam topsoil over $a \sim 30 \mathrm{~cm}$ milled oxide rock layer placed directly on sulphidic tailings from the Stawell Gold Mine, Southeast Victoria, Australia. Studies on soil strength and rooting characteristics of both native grasses are critical for the adoption of suitable mine tailing management practice for sustainable mining. The potential of the two perennial native grasses as erosion control plants was investigated in terms of its capacity of root reinforcement and root profile. The preliminary experimental results showed that both grass species studied exhibited good geomechanical characteristics in stabilising soil against erosion and increasing soil shear strength by up to $123 \%$ (T. triandra) and 73\% (B. macra) at $96 \mathrm{kPa}$ confining pressure. Soil shear strength increases with increasing root density $(R D)$ and root area ratio (RAR). The soil-root matrix significantly affects the apparent cohesion. The effect varies with distance away from grass centre depending on root density and root area ratio.
\end{abstract}

\section{Introduction}

Soil is regarded as one of the most precious resources in the world. With increasing human activities, however, soil erosion is accelerating and emerging as a global problem. For example, it is estimated that onefifth of agricultural land and tropical forest topsoil has been lost in the past 50 years (Cazzuffi et al., 2006). Soil erosion occurs by soil being blown or washed from land. It can lead to a serious threat to surrounding environments, as the wind-based transportation of dust from the degraded areas and the run-off of contaminated water can pollute surrounding areas (Wong and Bradshaw, 2002). Moreover, it can result in catastrophic problems in local communities including landslide disasters.

Soil bioengineering approaches often use locally-available materials and require minimum heavy equipment. They can offer inexpensive alternative solutions to resolve local environmental problems, leading to many obvious advantages including wildlife habitat establishment and aesthetic improvement. Generally, vegetation can perform a number of mechanical and hydrological functions: i) support; ii) anchor; iii) drain; iv) reinforce; and v) armour (Gray and Barker, 2004). Which or how many specific functions are performed by the plants in a soil bioengineering approach will depend on the plant species and the nature of the soil. For 
example, some plant root systems perform a mechanical contribution by reinforcing the soil to form a composite soil layer.

Currently, the cost of dealing with contaminated mine tailings is a major environmental liability for the minerals industry (Turlough, 2002). Using soil bioengineering approaches as described previously, however, have added a whole new dimension to tailings revegetation and restoration. Selection of heavy metal and metalloid tolerant plant species that thrive in contaminated areas like tailings storage facilities (TSF) can be used to stabilise contaminants like arsenic (As) and heavy metals. Closure of a TSF using native grasses can potentially stabilise the capped surfaces which in turn transforms the TSF from an expensive liability into an environmental and economic windfall. The concept means a main shift in the way tailing dam and mine wastes are managed and rehabilitated.

Grasses have been the dominant vegetation type in large areas of Australia for hundreds of thousands of years, with their success attributed to their survival in harsh conditions. Many native grasses are perennial, deep-rooted and tolerant of acidic soils, and they may play a role in helping to solve the problems of water erosion, induced soil acidity and dry land salinity (Whalley et al., 2005). Various native grasses have adapted to weathered and shallow soils; which make then ideal for planting on roadsides and mine-sites where topsoil is often returned as a veneer over reconstructed subsoil, on which many plants cannot establish (Huxtable, 1999; Huxtable, 2000; Huxtable et al., 2005). High summer temperatures can often burn and dry-out vegetation, however many native grasses can tolerate high temperatures, and frequently can respond to summer rainfall by retaining this slow-growing but active state over summer (Davies and Lefroy, 2005).

The aim of this preliminary study was to investigate the impact of native grass roots on the stability of a soil cover used in a TSF. The main objective was to evaluate the relationship between the root architecture of two native grasses and their stabilisation effects on the cover soil, as quantified by the improvement in soil strength.

\section{$2 \quad$ Materials and methods}

\subsection{Field site}

Stawell Gold Mine (latitude $37^{\circ} 03^{\prime} 59 \mathrm{~S}$, longitude $142^{\circ} 48^{\prime} 15 \mathrm{E}$ ) is located approximately $250 \mathrm{~km}$ northwest of Melbourne, Victoria. It is the longest operating gold mine in Australia with gold extracted in two periods: the Victorian gold rush in 1855-1920 with 2.6 million ounces of gold being recovered, and then reopened from 1984 to the present day. It remains the largest operating gold mine in the state with 1.5 million ounces mined in the last 15 years (c. 120,000 ounces production in 2008). Current mining activity is centred on the underground development which follows the Magdala lode system down plunge, and until recently between a depth of 470 and $786 \mathrm{~m}$. The mine and processing plant are approximately $3 \mathrm{~km}$ west of the town of Stawell. The local climate is temperate (mean January daily maximum temperature is $27.4^{\circ} \mathrm{C}$, mean July daily minimum is $4^{\circ} \mathrm{C}$ ), with maximum rainfall occurring between May and September (mean annual rainfall $576 \mathrm{~mm}$ ). Serious to severe rainfall deficiencies have occurred in the period 1999-2007, over most of eastern Australia including Stawell (Bureau of Meteorology, 2007).

Gold extraction is through a carbon-in-pulp cyanidation process. The ore is milled and processed to form slurry. The tailings slurry is then deposited into a TSF (Tailings Dam No. 2) of $\sim 100$ ha surface area. This TSF, at the time of mine closure, will contain a minimum of 10 million tonnes of tailings with the original sulphide content of the ore around 2-6\%. Tailings reflect mineralogy and chemical composition of ores processed for mineral recovery. Mineralisation in the auriferous quartz veins at Stawell is made up of approximately $85-95 \%$ quartz, $5-10 \%$ sulphides which are predominantly pyrite with lesser amounts of arsenopyrite, pyrrhotite, sphalerite and chalcocite, 1-3\% carbonates which are mainly ankerite, calcite, ferroan dolomite and trace amounts of siderite, with biotite, muscovite and chlorite present in small quantities (Mapani 1995). Characteristically of the Victorian Goldfields, the tailings contain significant quantities of arsenic, present in pyrite as well as in the arsenopyrite. Acid/base accounting of tailings deposited during the period of this study shows them to be 'non-acid producing' or occasionally very weakly acid-producing. Net acid producing potential (NAPP) of 48 samples from the main experimental facility (TERF) had an average maximum potential acidity (MPA) of $106.23 \mathrm{~kg} \mathrm{H}_{2} \mathrm{SO}_{4} / \mathrm{t}$ and an acid neutralising capacity (ANC) of $147.82 \mathrm{~kg} \mathrm{H}_{2} \mathrm{SO}_{4} / \mathrm{t}$, i.e. NAPP $=-41.58 \mathrm{~kg} \mathrm{H}_{2} \mathrm{SO}_{4} / \mathrm{t}$. Minor carbonate contributes to the 
ANC, which is however dominantly accredited to the large (>40\%) content of chlorite and chloritoid able to exchange cations, including $\mathrm{H}^{+}$.

The active TSF (Tailings Dam No. 2) has been developed within a shallow dammed valley and is fed by marginal spigots. Process lime gives the tailings slurry a $\mathrm{pH} \sim 10.5$ at the time of deposition and buffers any immediate acidification. The initial mine closure plan called for the capping of the TSF with a minimum of $10 \mathrm{~cm}$ of impermeable material (clay) and a further $30 \mathrm{~cm}$ cover of compacted inert material, and then soil and other fill material of sufficient depth to enable root development. While milled oxide ore and waste rock could provide a large part of the latter, clay is not locally available. The recommended regulatory revegetation strategy is to create grassland rather than a vegetation community which comprise deep rooted shrub and tree species to minimise root penetrating into the tailings, hence to minimise uptake of arsenic by the plants. This prescription may not be a realistic option as plant roots will invariably reach the tailings material.

Construction of a tailings experimental research facility (TERF) commenced in September 2001 which was located on the surface of an older TSF (Tailings Dam No. 1), with an aim of providing a physical and geochemical environment similar to that envisaged at the time of rehabilitation of the current TSF. In situ surface tailings were bulldozed to build $\sim 3 \mathrm{~m}$ high walls forming two experimental cells each with a plan dimension of $75 \times 155 \mathrm{~m}$. Fresh sulphidic tailings were poured from spigots positioned around the periphery of each cell in the same manner as in the current TSF. The filling of TERF took four months and was completed in May 2002. Perforated PVC pipes were laid at the base of TERF before filling to allow collection of drainage water and to speed up the drying time of the tailings. Experimental plots were created in September 2002 when the surface of the tailings had sufficiently consolidated to allow the use of earthmoving machinery. The trial cover was implemented in November 2006 on the sulphidic tailings which by then had been exposed to weather, and have been oxidised for four years. The soil layers employed in the trial cover included:

- $5 \mathrm{~cm}$ thick topsoil: material stockpiled from the top $10 \mathrm{~cm}$ of the original land surface when it was removed by previous mining activities, e.g. open cuts and tailings storage facility floors. Unfortunately, former mining practice did not recognise the value of this topsoil for future mine reclamation. It is estimated that there is sufficient topsoil to cover $80 \%$ of the final cover system. The typical topsoil in the mining area is a slightly acidic sandy loam (pH 5.5) with low electrical conductivity $\mathrm{EC}<0.5 \mathrm{mS} / \mathrm{cm}$.

- $\quad 30 \mathrm{~cm}$ thick oxide waste or mud soil layer: a waste stockpile resulting from former open-cut mining of the oxidised zone with an estimated volume of 2.5 million $\mathrm{m}^{3}$. This represents the largest local source of future potential capping material and should be sufficient to cover the entire final area of the TSF. The oxidised and heavily leached waste rock was milled to produce a fine material that was shown in glasshouse trials to be chemically benign with an alkaline $\mathrm{pH}$ (8.2), low electrical conductivity $\mathrm{EC}<0.5 \mathrm{mS} / \mathrm{cm}$ and no net acid generation potential).

Native grass seeds were supplied by Native Seeds Pty Ltd and were germinated, propagated and maintained in standard forestry tubes. After two months, the grass seedlings were planted as plugs at a spacing of $30 \mathrm{~cm}$. The planting was conducted in January 2007. The seedlings were irrigated with a porous hose irrigation unit for the first (Australian) summer. Two warm season native grasses (Figure 1) were selected for the study, kangaroo grass (Themeda triandra Forssk) and red grass (Bothriochloa macra (Lindl.) Lazarides). Both indigenous grasses were favoured for their ability to grow on acidic soils with low fertility, and persistence under low or variable rainfall conditions. Kangaroo grass is a tufted perennial grass that is highly variable in appearance and size, ranging from $0.3-1.5 \mathrm{~m}$ in height. It has been shown to be a feasible option for gold mine rehabilitation in NSW (Windsor and Clements, 2001). Red grass is a low-growing tussock grass with greenish to brownish sparsely hairy leaves, but it can reach up to $1 \mathrm{~m}$ high when the slender reddish-purple flowering stems are produced during summer and early autumn, hence the common name 'red grass'. 

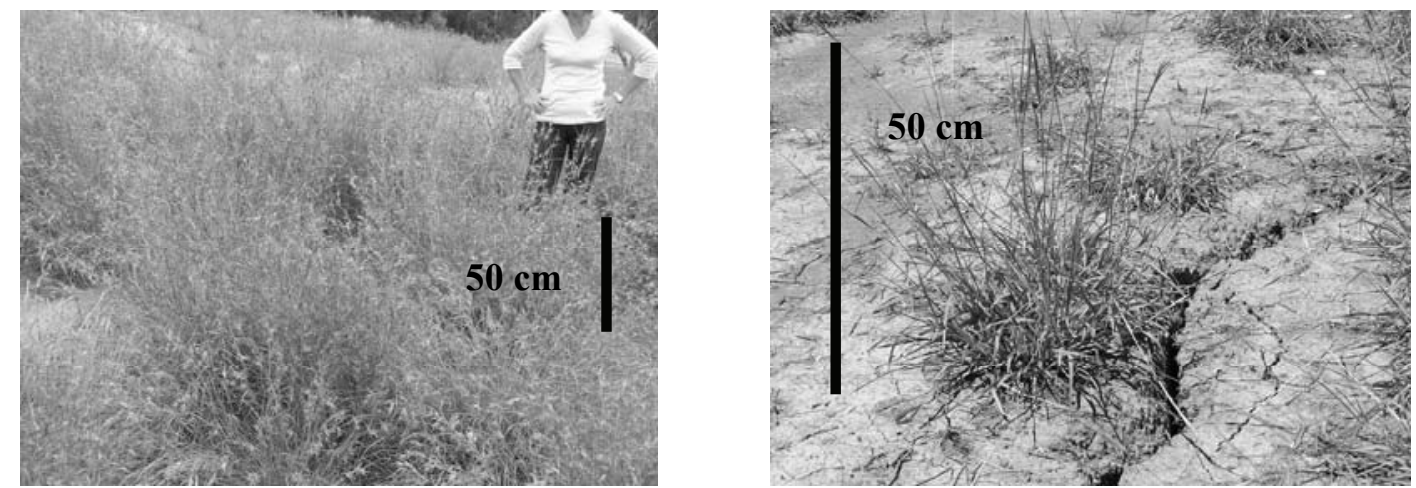

Figure 1 Growth form and habit of kangaroo grass (Themeda triandra Forssk) and red grass (Bothriochloa macra (Lindl.) lazarides) respectively (images courtesy of I. Chivers)

\subsection{Laboratory and field investigation}

This study investigated the role of the two native grass roots in stabilising the trial cover. The investigation was focused at a depth from $0.1-0.2 \mathrm{~m}$ in the mud soil layer. Soil cores of about $40 \mathrm{~cm}$ in length were obtained by pushing $50 \mathrm{~mm}$ inner diameter sampling tubes into the cover. Thin-walled samplers were used to minimise soil sample disturbance, although soil sample structure may have been further disrupted while some roots were cut by the action of pushing the tubes down. A total of seven cores were taken around each individual grass. Figure 2 shows the designed sampling locations and the numbering of samples. The first sampling point (1-1) was set in the centre of the grass. The next three sampling points (2-1 to $2-3)$ were then set surrounding the centre sample in an equilateral triangular pattern with each side of $11 \mathrm{~cm}$. Finally, the remaining three sampling points (3-1 to 3-3) formed a bigger equilateral triangle with a $22 \mathrm{~cm}$ side. These patterns were designed to retrieve samples at similar radial distances from the centre of the individual grass, with similar root architectures expected in the two sets of radial distances.

The soil samples collected from the mud soil layer were characterised using standard soil laboratory tests. A summary of these results are presented in Tables 1 and 2. In this preliminary study, the consolidated undrained (CU) triaxial test (ASTM D-4767) was chosen because it can provide necessary parameters for drained and undrained analyses (i.e. short term and long term).
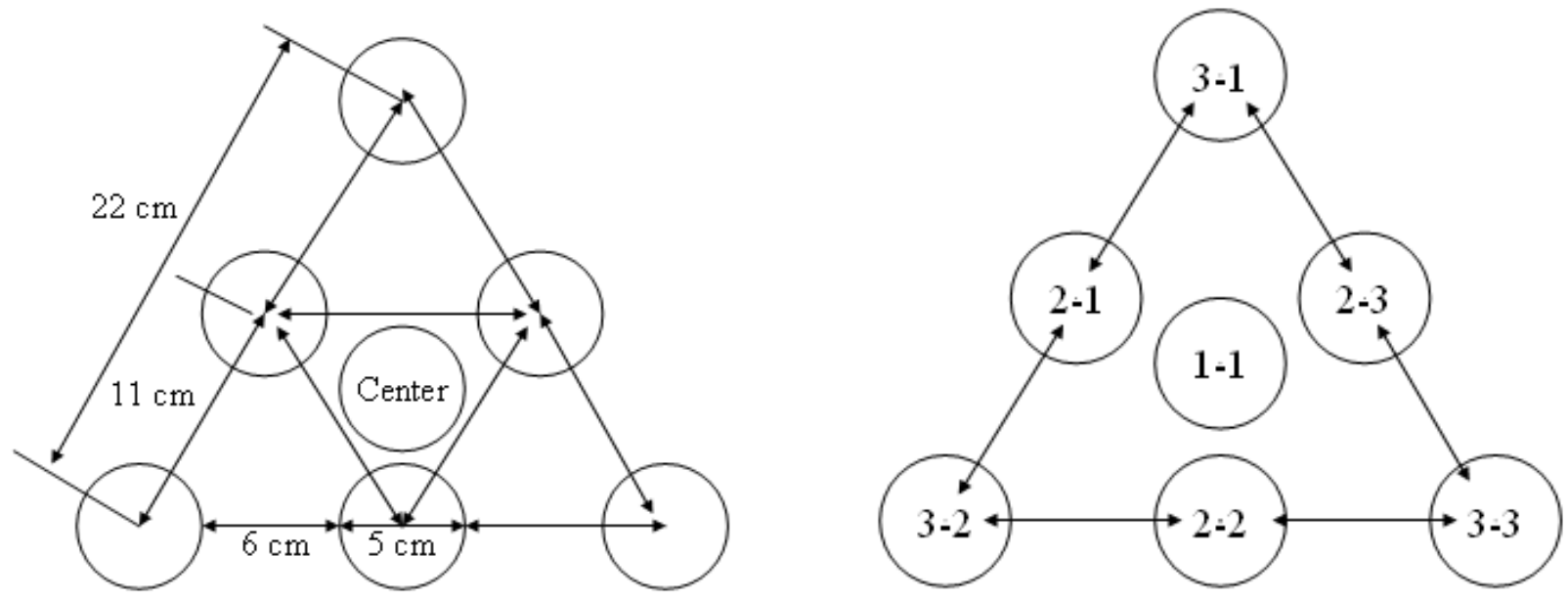

Figure 2 Designed sampling locations and numbering of samples (plan view) 
Table 1 Particle size distribution (mud soil) (AS 1289)

\begin{tabular}{lll}
\hline PSD Fraction & Fraction PSD Range & $\begin{array}{l}\text { Percentage } \\
\text { Mud Soil }\end{array}$ \\
\hline Clay fraction & Particle size $<0.002 \mathrm{~mm}$ & 12 \\
Silt fraction & $0.002 \mathrm{~mm}<$ particle size $<0.06 \mathrm{~mm}$ & 11 \\
Sand fraction & $0.06 \mathrm{~mm}<$ particle size $<2 \mathrm{~mm}$ & 76 \\
Gravel fraction & $2 \mathrm{~mm}<$ particle size & 1 \\
\hline
\end{tabular}

Table 2 Basic soil engineering properties (mud soil) (AS 1289)

\begin{tabular}{ll}
\hline Basic Engineering Properties & \\
\hline Moisture content & $17.8 \%$ \\
Liquid limit & $42.1 \%$ \\
Plastic limit & $21 \%$ \\
Linear shrinkage & $3.34 \%$ \\
Plastic index & $21.1 \%$ \\
Emerson class number & 5 \\
Soil classification according to PSD United States & Sandy loam \\
Department of Agriculture (USDA) & \\
Unified soil classification system & SC \\
\hline
\end{tabular}

\subsection{Root architecture studies}

Live roots separated from the soil samples after triaxial tests were scanned and analysed by the WinRHIZO system which comprised of a specially designed software package and computer-linked digital scanner. The WinRHIZO system measured the total root length, total surface area, average diameter, and number of roots. Root area ratio $(R A R)$ or root biomass concentration as a function of soil depth are required in order to estimate root contribution to soil strength. $R A R$ is defined as the fraction of the soil cross-sectional area occupied by roots per unit of area (Smit et al., 2000). In this study, $R A R$ was calculated using the root length density $(R L D)$ and root diameter $(D)$ (Gray and Leiser, 1982). First the values of $R L D$ and $D$ were calculated using Equations (1) and (2), respectively:

$$
R L D=L / V
$$

where $L$ is length of the living roots $(\mathrm{m})$ and $V$ is the volume of soil sample $\left(\mathrm{m}^{3}\right)$, and:

$$
D=A / N
$$

where $A$ is the total surface area of the living roots $\left(\mathrm{m}^{2}\right)$ and $N$ is the number of living roots.

In this study, the root growth direction was assumed to be vertical with root branches parallel to the main root. Therefore, the root diameters for each grass were approximately constant. The total root length $(\mathrm{m})$ in 1 $\mathrm{m}^{3}$ of soil is then multiplied by the mean cross-sectional area $\left(\mathrm{m}^{2}\right)$ of a grass root:

$$
R A R=R L D \times R C S A
$$

where $R C S A$ is the mean cross-sectional area of a single root $\left(\mathrm{m}^{2}\right)$.

After the above test, the washed roots were air-dried for three days for measurement of the biomass. Roots were weighted using a scale with a precision of $0.001 \mathrm{~g}$. An average root density $(R D)$ was determined according to the volume $V\left(\mathrm{~m}^{3}\right)$ of the core and expressed as $\mathrm{kg} / \mathrm{m}^{3}$ :

$$
R D=M / V
$$


where $M$ is dry living root mass $(\mathrm{kg})$ and $V$ is the volume of the soil cylinder containing the root-soil matrix $\left(\mathrm{m}^{3}\right) . R D$ was calculated per soil sample.

\section{$3 \quad$ Results and discussion}

\subsection{The influence of root density on soil shear strength}

Figure 3 shows the relationship between root density and soil shear strength, with all tests conducted under the same confining pressure $(96 \mathrm{kPa})$, and $0.075 \% / \mathrm{min}$ compressive axial strain rate to allow pore pressure equalisation within the sample.

While the graphs of both grass species indicate clearly the effectiveness of root density in increasing shear strength, it can be observed that the root density of kangaroo grass (Figure 3a) is generally higher than the red grass (Figure 3b) at the same sampling point, i.e. at same radial distance from the grass centre. Consequently, the soil samples collected around the kangaroo grass exhibited higher shear strength than the red grass samples.

Due to the limitation that only one set of soil samples was recovered and tested for each grass species, these shear strengths values should be taken only as indicative, and further testing is needed to confirm repeatability and account for variability in soil and root architecture. Nevertheless, these preliminary results suggest that the mud soil would be in its most unfavourable state in terms of shear strength without reinforcement from the root system. The stability of the soil cover would therefore be improved with increasing root density, which is in agreement with the observations by Gyssels and Poesen (2003).

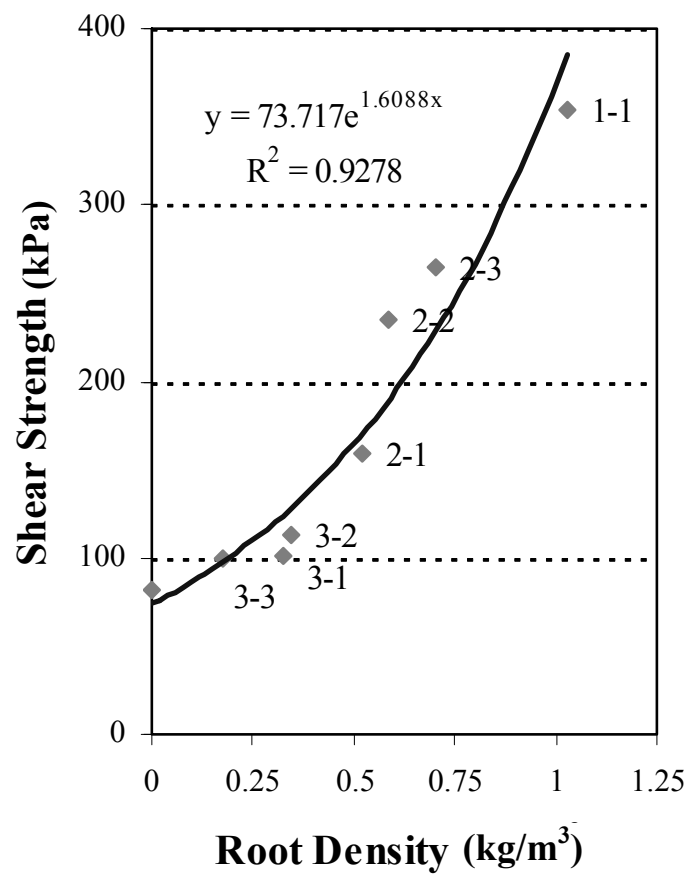

(a)

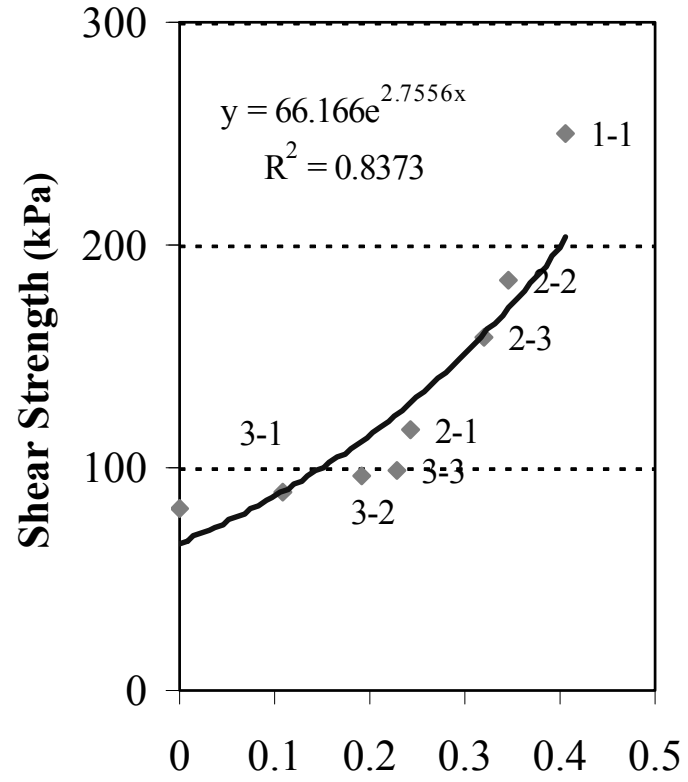

Root Density $\left(\mathrm{kg} / \mathrm{m}^{3}\right)$

(b)

\section{Figure 3 Relationship between shear strength and root density - (a) kangaroo grass and (b) red grass. Saturation ratio $=0.95$}

The investigation also evaluated the change of apparent soil strength parameters caused by an increase of root density. Although it is rather meaningless to interpret the root-reinforced results in terms of improvements in strength components (cohesion and friction angle) as a parameter such as friction angle has no meaning in a reinforced system, the apparent cohesion values $C$, which was obtained assuming a MohrCoulomb failure envelope for two parallel soil samples at confining stresses of 24 and $96 \mathrm{kPa}$, can be linearly correlated with root density $R D$. The mean $C$ values obtained from this study were lower than those 
generally found in the literature, which were calculated using the root reinforcement model (O'Loughlin and Ziemer, 1982; Abernethy and Rutherfurd, 2001; Van Beek et al., 2005; Mickovski and Van Beek, 2006). Nevertheless, this situation could be explained by an overestimation of the $R A R$, because in the model all roots contained in one soil sample were regarded as being strongly perpendicularly oriented when crossing the shear zone, even though this was not the case in the field, with a more random orientation of all roots within the soil masses tested. Although it has been suggested that the fibres which are oriented perpendicular to a shear zone add reinforcement nearly comparable to that of randomly oriented fibres (Schmidt et al., 2001). The diameters of roots are also a critical factor for $R A R$. In addition, the relative higher value for $C$ calculated by the model may be led by an assumption that all roots crossing the shear plane will exert their ruptured tensile strength simultaneously. In fact, the roots contained in the soil have different values of tensile strength and will be exerted progressively, which results in roots rupturing at different times (Mickovski et al., 2008). These reasons may lead to a $40 \%$ overestimation of additional cohesion force by the model (Pollen and Simon, 2005).

\subsection{The root architecture}

The root area ratio $R A R$ distributions calculated for both grass species are shown in Figure 4. Overall, the $R A R$ of kangaroo grass ranged from 0.033 to $0.498 \%$ (Figure 4a). Meanwhile, the $R A R$ for the red grass sample plots ranged from 0.019 to $0.471 \%$ (Figure $4 \mathrm{~b}$ ). It is evident that, for both grass species, the mean $R A R$ value for soil sample 1-1 was significantly higher than samples further away from the centre, as almost all grass roots are present in this centre location. Also, the distribution of roots over the inner sample triangle points (i.e. $2-1,2-2$, and 2-3) are generally higher than the outer triangle. This general trend is observed in both grass species.
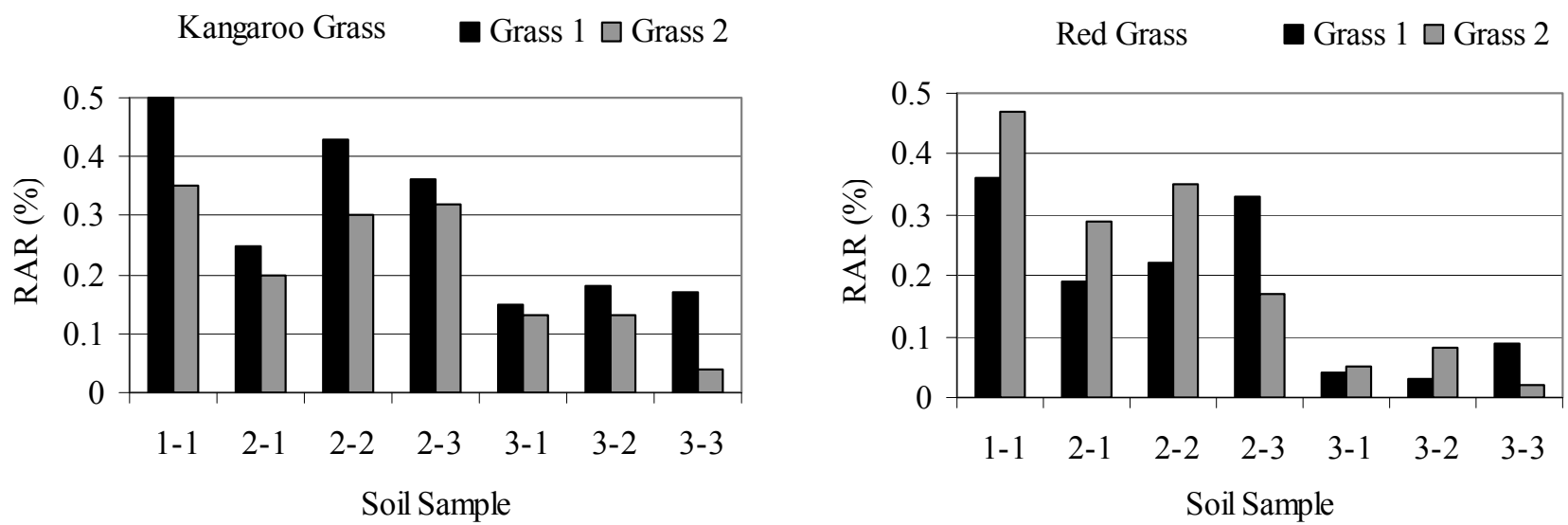

Figure 4 Root area ratio (RAR) values for both grass species $(10 \mathrm{~cm}$ depth)

\subsection{Stress-strain behaviour}

Figure 5 plots the stress-strain behaviour of a selected kangaroo grass sample (2-3) and a selected red grass sample (2-3), together with a bare soil sample for comparison (confining pressure, $96 \mathrm{kPa}$ ). While the maximum shear strength of the kangaroo grass was higher than the red grass as discussed in the previous section, the two grass samples shared a similar failure pattern. Initially there was a rapid increase in the tensile resistance with minimal displacement of the root, followed by a more gradual increase as the root started to distort and deform. In contrast, the shear stress of the soil-without-roots sample behaved quite differently, reaching its peak at a relatively small strain (about 7\%) and then dropping off gradually as strain increased. The above indicates that there is a significant impact of plant roots on the soil's shear strength as well as its stress-strain behaviour. This observation is in line with the findings from Riestenberg (1994) and Abernethy and Rutherfurd (2001), that a high root area ratio tends to lead to a larger shear stress and a larger failure strain. Roots increase soil shear strength by anchoring a soil layer and by forming a binding network within the layer (Waldron and Dakessian, 1982; Schmidt et al., 2001). 


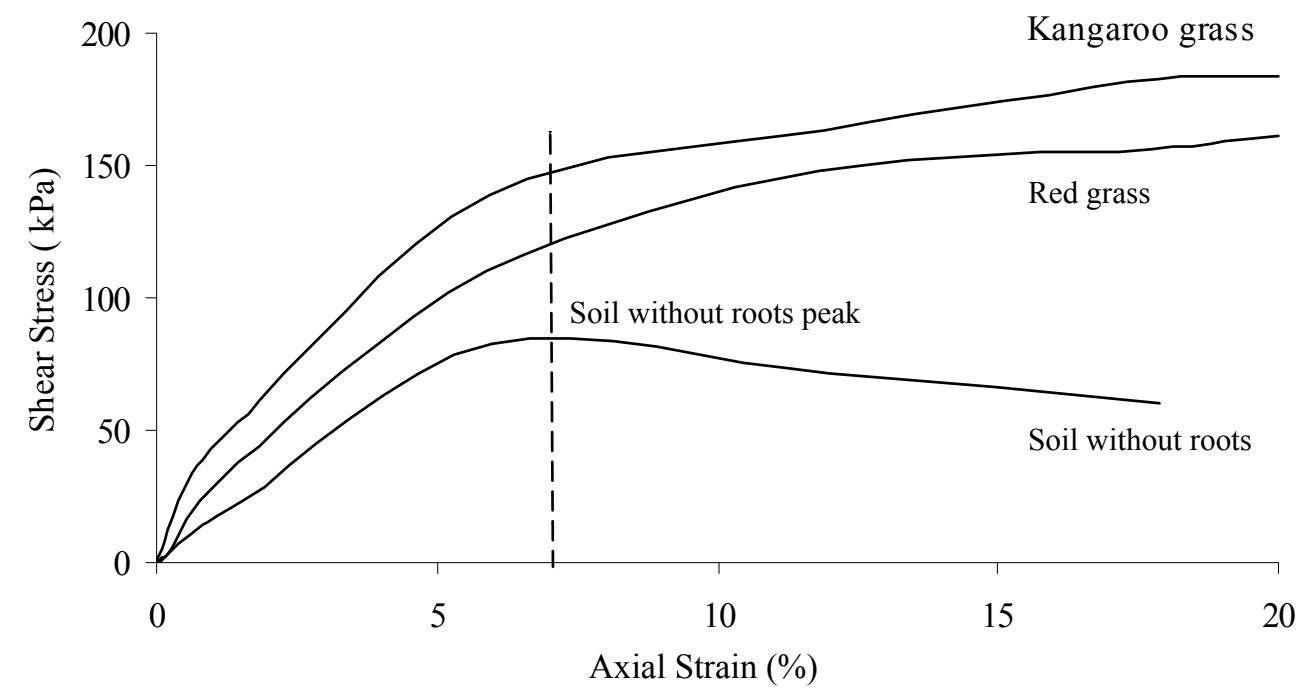

\section{Figure 5 Typical stress-strain behaviour of samples with and without root reinforcement (for the two tested grass species) (96 kPa confining stress)}

\section{Conclusions}

The following specific conclusions can be drawn from this preliminary study.

The analysis of the relationship between soil shear strength and root critical indicators suggest that there is a high variation of shear strength for both grass species - kangaroo grass ( $T$. triandra) and red grass (B. macra). Soil shear strength was higher at the centre of the grass, and decreased as the sampling extended away from the centre, which reflects a reduction in root density.

Using native grasses, the soil shear strength of the composite soil was demonstrated to increase up to $\sim 123 \%$ (kangaroo grass) and $\sim 73 \%$ (red grass) respectively, under a $96 \mathrm{kPa}$ confining stress. Because of the better established root architecture, the shear strength of mud soil reinforced with kangaroo grass was significantly higher than the red grass. For both grass species the maximum shear stress was reached at a significantly larger displacement than for the soil-without-roots test.

The finding has also provided new empirical information on the differential response of native grass species which would provide better prescriptions on appropriate species selection for long term restoration of reclaimed land surfaces such as on a tailings storage facility. Further studies are currently being undertaken to evaluate several more native grass species growing on this remade mine surface as the system has been validated with these initial two species.

Given the high adaptability of both grasses growing in the trial cover since November 2006, both grass species have the potential to be used successfully to stabilise the mud soil cover overlying the sulphidic tailings deposit.

\section{Acknowledgements}

The authors acknowledge the support of an ARC Linkage grant LP0562084, Industry Partners Stawell Gold Mine and Ian Chivers of Native Seeds Pty Ltd.

\section{References}

Abernethy, B. and Rutherfurd, I.D. (2001) The distribution and strength of riparian tree roots in relation to riverbank reinforcement, Hydrological Processes 15, pp. 63-79.

Australian Standards (AS) 1289.0 (2000) Methods of testing soils for engineering purposes - Part 0: General requirements and list of methods, Standards Association of Australia.

Bureau of Meteorology (2007) Annual Climate Statement 2006: A year of climate contrasts, issued January 2007, viewed 17 June 2009, http://www.bom.gov.au/announcements/media_releases/climate/change/20070103.shtml. 
Cazzuffi, D., Correo, A. and Crippa, E. (2006) Slope stabilisation by perennial "gramineae" in Southern Italy: plant growth and temporal performance, Journal of Geotechnical and Geological Engineering, 24, pp. 429-447.

Davies, C. and Lefroy, T. (2005) Native Grasses - a natural choice for Australian agriculture, Australian Plants, 23, $184 \mathrm{p}$.

Gray, D.H. and Barker, D.H. (2004) Root-soil mechanics and interactions, Riparian Vegetation and Fluvial Geomorphology: Hydraulic, Hydrologic, and Geotechnical Interactions, S.J. Bennet, A.J.C. Collison and A. Simon (eds), Water Science and Application 8, American Geophysical Union, Washington.

Gray, D.H. and Leiser, A.T. (1982) Biotechnical slope protection and erosion control, Van Nostrand Reinhold Company, $271 \mathrm{p}$.

Gyssels, G. and Poesen, J. (2003) The importance of plant root characteristics in controlling concentrated flow erosion rates. Earth Surface Processes and Landforms 28, pp. 371-384.

Huxtable, C.H.A. (2000) The use of native grasses in mine rehabilitation in Australia: a review. In: Better Pastures, naturally. Proceedings of the First Native Grasses Conference, Mudgee, NSW, C.M. Waters (ed), NSW Agriculture, Trangie, pp. 10-29.

Huxtable, C.H.A. (1999) Rehabilitation of open cut coal mines using native grasses: management guidelines: project C3054, Australian Coal Association Research Program, 200 p.

Huxtable, C.H.A., Koen, T.B. and Waterhouse, D. (2005) Establishment of native and exotic grasses on mine overburden and topsoil in the Hunter Valley, New South Wales, The Rangeland Journal 27, pp. 73-88.

Mapani, B.S.E. (1995) Structural evolution and mineralization at the Magdala gold mine, Stawell, Western Victoria. Earth Sciences, PhD Thesis, University of Melbourne, p. 303.

Mickovski, S.B. and Van Beek, L.P.H. (2006) A decision support system for the evaluation of eco-engineering strategies for slope protection, Geotechnical and Geological Engineering 24, pp. 483-498.

Mickovski, S.B., Hallett, P.D., Bengough, A.G., Bransby, M.F., Davies, M.C.R. and Sonnenberg, R. (2008) Advances in GeoEcology, No. 41 Proceedings of the 5th international congress of ESSC - European Society for Soil Conservation (Changing Soils in a Changing World: the Soils of Tomorrow - Palermo June 25-30, 2007), p. 117.

O’Loughlin, C.L. and Ziemer, R.R. (1982) The importance of root strength and deterioration rates upon edaphic stability in steepland forests, Carbon uptake and Allocation in Subalpine Ecosystems as a key to Management, IUFRO Workshop, Corvallis, Oregon, pp. 70-78.

Pollen, N. and Simon, A. (2005) Estimating the mechanical effects of riparian vegetation on stream bank stability using a fiber bundle model, Water Resource 41, pp. 1-11.

Riestenberg, M.M. (1994) Anchoring of thin colluvium by roots of Sugar maple and White ash on hillslope in Cincinnati, US Geological Survey Bulletin 2059, pp. 1-25.

Schmidt, K.M., Roering, J.J., Stock, J.D., Dietrich, W.E., Montgomery, D.R. and Schaub, T. (2001) The variability of root cohesion as an influence on shallow landslide susceptibility in the Oregon Coast Range, Canadian Geotechnical Journal 38, pp. 995-1024.

Smit, A.L., Bengough, A.G., Engels, C., van Noordwijk, M., Pellerin, S. and van de Geijin, S.C. (2000) Root Methods, a Handbook, Heiderberg, $587 \mathrm{p}$.

Turlough, F.G. (2002) Heavy equipment maintenance wastes and environmental management in the mining industry, Journal of Environmental Management 66, pp. 185-199.

van Beek, L.P.H., Wint, J., Cammeraat, L.H. and Edwards, J.P. (2005) Observation and simulation of root reinforcement on abandoned Mediterranean slopes, Plant Soil 278, pp. 55-74.

Waldron, L.J. and Dakessian, S. (1982) Effect of grass, legume and tree roots on soil shearing resistance, Soil Science 46, pp. 894-899.

Windsor, D.M. and Clements, A.M. (2001) A germination and establishment field trial of Themeda australis (kangaroo grass) for mine site restoration in the central tablelands of New South Wales, Restoration Ecology 9(1), pp. 104-110.

Whalley, R.D.B., Friend, D.A., Sandford, P. and Mitchell, M.L. (2005) Evaluation of native and introduced grasses for low-input pastures in temperate Australia: rationale and scope, The Rangeland Journal 27, pp. 1-9.

Wong, M.H. and Bradshaw, A.D. (2002) The Restoration and Management of Derelict Land, Modern Approaches, pp. 138-148. 